\title{
Understanding the Conceptual Evolutionary Path and Theoretical Underpinnings of Corporate Social Responsibility and Corporate Sustainability
}

\author{
Mehrnaz Ashrafi ${ }^{1, *}$, Gregory M. Magnan ${ }^{2}$, Michelle Adams ${ }^{1}$ and Tony R. Walker ${ }^{1}$ (i) \\ 1 School for Resource and Environmental Studies, Dalhousie University, Halifax, NS B3H 4R2, Canada \\ 2 Albers School of Business and Economics, Seattle University, Seattle, WA 98195, USA; \\ gmagnan@seattleu.edu (G.M.M.); adamsm@dal.ca (M.A.); trwalker@dal.ca (T.R.W.) \\ * Correspondence: mehrnaz.ashrafi@dal.ca
}

Received: 21 December 2019; Accepted: 19 January 2020; Published: 21 January 2020

\begin{abstract}
To unlock the potential for corporations to play a more proactive role in sustainable development, it is critical to have a fundamental understanding of the pathways leading to a responsible and sustainable business. This study explores contributions of theories of the firm in explicating why and how integrating corporate social responsibility (CSR) and corporate sustainability (CS) into business strategic decisions and operation processes helps to improve the viability of corporations. The research objective is addressed through a narrative review of relevant literature by following the developmental and evolutionary sequences in business responsibility and sustainability while contemplating the connections between CSR and CS through the lens of the dominant theoretical perspectives underpinning the concepts. The study posits an integrative theoretical framework that offers supports for embedding CSR and CS into a corporate business strategy. It discusses that corporate choice of CSR and CS actions and policies is supported by dual internal and external mechanisms based on resource-based theory and institutional theory. This is to meet the interests and expectations of internal and external stakeholders, the basis upon which stakeholder theory is constructed. Findings from this review corroborate the proposition that the three theories of resource-based, institutional, and stakeholder could be used as the primary approach to explain corporate recognition of the need for CSR and CS, and further build a coherent platform to support corporate choice and adoption of CSR and CS in business strategy.
\end{abstract}

Keywords: sustainable development; corporate social responsibility (CSR); corporate sustainability (CS); institutional theory; resource-based theory; stakeholder theory

\section{Introduction}

The discourse on the role of businesses in society has a long history, and with the growing environmental and social challenges facing society, this role has received increasing scrutiny from various quarters [1,2]. Individual corporations are looking beyond the traditional profit-making goals, rethinking their impacts on society and the environment, and seeking to identify ways to cultivate positive and sustainable relationships with stakeholders [3]. Improved social and environmental performance can provide both tangible benefits such as cost reduction and risk management, and intangible benefits such as enhanced reputation and increased competitiveness [2]. The potential for corporations to contribute positively to society and the environment, in addition to maximizing profits, has become a shared focus for both scholars and practitioners [4]. Operationalizing this potential has been the crux of the emergence of corporate social responsibility (CSR) and corporate sustainability (CS). 
Both CSR and CS have flourished within the last two decades. During that time, researchers have developed a wealth of knowledge regarding the role of businesses and the ability to deliver social and environmental benefits concurrently with economic growth [5]. While some studies use CSR and CS interchangeably in their research [6], others take the opposing position. Bansal and Song [7], in particular, argue that each concept originated independently via a different pathway, but both have converged to the same place, using similar definitions, ontological assumptions, nomological networks, and measurement. The authors suggest that rather than assuming both constructs are the same, scholars need to explore the distinctiveness, complementarities, and integration of these two research traditions [7]. A more recent study by Ashrafi et al. [8] builds on the work of Bansal and Song [7] and offers insight on how CSR can be integrated into CS as either a transitional stage or ultimate goal for a corporation, rather than necessitating that the concepts remain wholly separate. Although these definitional developments have brought CSR and CS ever closer together $[7,8]$, the common theoretical perspectives underpinning both CSR and CS still need more attention and a thorough discussion.

Moreover, a recent study of research trends on CSR and CS using the bibliometric method, by Abad-Segura et al. [9], called for a qualitative study to review the relationship between CSR and CS in order to pinpoint overlaps, which can help to understand underlying conditions that the determine the integration of CSR and CS into a corporate business model. In the absence of studies with such a clear focus, this paper traces the conceptual evolutionary path of CSR and CS (together with its counterpart term of sustainable development from which it emanated) in depth while contemplating the connections between the two through a number of theories of the firm. The study intends to provide insights into theoretical developments supporting corporate recognition and adoption of CSR and CS in their business strategy. "Theories of the firm provide a perspective for thinking about organizational objectives and a framework for analyzing important research problems" [10] (p. 165). Several theories of the firm, such as agency theory, institutional theory, evolutionary theory, resource-based theory, social contract theory, and stakeholder theory, have been proposed within the business responsibility and sustainability research agenda to explain how corporations function within a framework of CSR and CS $[3,11]$. While there is no consensus on the most appropriate theories, this study discusses the application of institutional theory, resource-based theory, and stakeholder theory to frame the underlying grounds for integrating CSR and CS policies and actions into a corporate business strategy.

The objective of this study is addressed through a narrative overview of the literature. First, a broad search of keywords, such as "corporate social responsibility", "CSR", "corporate sustainability", "CS", "sustainability", "sustainable development", "institutional theory", "resource-based" and "stakeholder" in the following 10 high-impact management journals was conducted: Academy of Management Review, Journal of Business Ethics, Strategic Management Journal, Organization E Environment, Journal of Cleaner Production, Business \& Society, Academy of Management Journal, Business Strategy and the Environment, Corporate Social Responsibility and Environmental Management, and Journal of Management Studies. Titles and/or abstracts of articles found in these journals were examined to identify a representative set of research articles that address the intersection of CSR/CS and institutional theory/resource-based theory/stakeholder theory. The relevant articles, whose contributions to this study account for more than half of all cited articles, were then thoroughly studied. The reference lists of these articles were also checked to identify any additional management-oriented articles to further evaluate the complete set of findings to form this narrative review. This resulted in a total of 91 management-oriented articles, out of the 123 articles that contributed to this study (Figure 1). The management-oriented journals, all of which are Q1, except the practitioner-oriented journal Harvard Business Review, are within the subject area and category of 'Business, Management and Accounting', 'Strategy and Management' and 'Social Sciences'. 


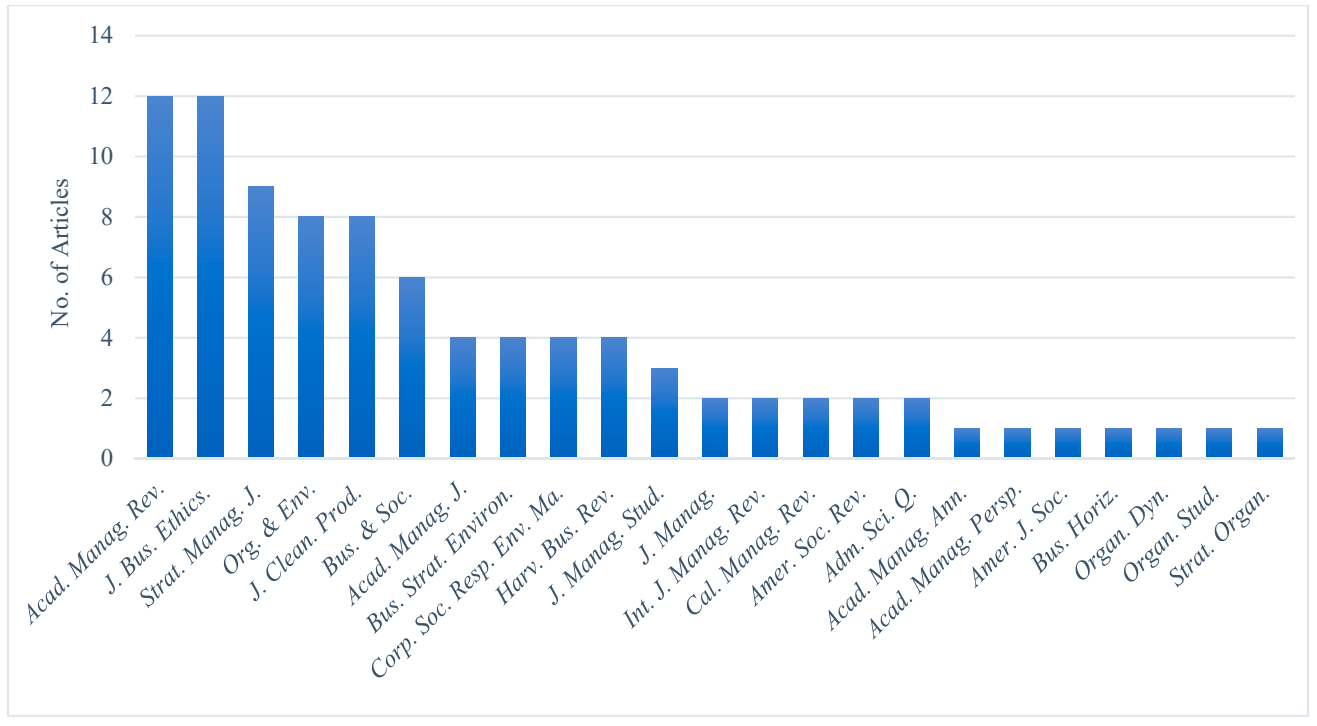

Figure 1. The management-oriented journals that contributed to the study.

\section{CSR and Theories of the Firm}

The root of CSR can be traced to the 1920s, embedded in the concepts of corporate philanthropy, social give-back, codes of conduct, community service, and corporate managers as public trustees [12]. Due to the influence of the Great Depression of the 1930s and World War II in the 1940s, CSR, however, failed to become a serious topic amongst leading corporations until the 1950s [13]. CSR found itself in the spotlight in 1951 when Frank W. Abrams, a former executive for Standard Oil Company, New Jersey, introduced the idea that businesses should be held accountable to society for their actions. He recognized the obligation of business managers "to conduct the affairs of the enterprise in its charge in such a way as to maintain an equitable and workable balance among the claims of the various ... interested groups: the stockholders, employees, customers, and the public at large" [14] (pp. 29-30). The modern era of CSR was, however, marked by Howard R. Bowen in 1953, who made the first significant scholarly contribution by publishing the book, Social Responsibilities of the Businessman [15]. He proposed the definition of CSR as "the obligations of businessmen to pursue those policies, to make those decisions, or to follow those lines of action which are desirable in terms of the objectives and values of our society" [16] (p. 6). In 1960, William C. Frederick, who has written extensively on CSR for decades, also recognized the social responsibilities of the businessman to "oversee the operation of an economic system that fulfills the expectations of the public. And this means in turn that the economy's means of production should be employed in such a way that production and distribution should enhance total socio-economic welfare" [17] (p. 60).

During the 1950s and 1960s, the focus of CSR was primarily on business responsibilities to society and acting in a socially responsible manner, and less so on how CSR could benefit the business [13]. It was not until the late 1950s that Theodore Levitt raised concerns about the dangers of pursuing ambiguous corporate objectives such as CSR-related activities [18] and openly criticized the concept. Similar arguments were made later by Milton Friedman, who purported that businesses have only one responsibility and it is to make as much money as possible for their shareholders while conforming to the basic rules of society $[19,20]$. Such views at the time constructed a new narrative around the notion of incorporating CSR into business objectives. For example, managers were perceived to be unfit for a role that rightly belongs to government, citing dangers such as distracting managers from profit-making tasks, or the potential misappropriation of shareholders' funds by executive managers in the name of CSR to advance their own social, political, or career agendas.

Over time, there were further efforts to establish a positive linkage between CSR and shareholders' long-term interests. A major debate on how to reconcile CSR with the economic interests of corporations 
emerged in 1970. Henry C. Wallich and John J. McGowan [21] recognized that it is consistent with shareholders' long-term interests to be socially minded, providing a new rationale to uphold CSR without compromising shareholders' interests [22]. On that note, Keith Davis [23], one of the first and most prominent CSR scholars of that period, recognized CSR as "the firm's obligation to evaluate in its decision-making process the effects of its decisions on the external social system in a manner that will accomplish social benefits along with the traditional economic gains which the firm seeks" (pp. 312-313). Most of the research in favor of CSR that followed supported the notion that it in a business's long-term self-interest, so-called 'enlightened self-interest', to be socially responsible [24-26]. While the 'enlightened self-interest' model enabled CSR to be more widely accepted by business managers, it did not provide any theoretical framework to connect CSR to the outcomes of socially responsible initiatives and identify the benefits to a wide range of stakeholders [22]. During this period, the concept of corporate social performance (CSP) was developed as an extension of CSR. CSP implies the capacity of a corporation to respond to social pressures and was pioneered by Robert W. Ackerman in 1973 [27]; it was later referred to as CSR $_{2}$ by Frederick [28].

By the mid-1970s, Prakash S. Sethi developed a structural framework to facilitate the analysis of CSR and its linkage to CSP. Sethi [29] recognized three stages for adoption of corporate behavior linked to social needs (i.e., social obligation, social responsibility, and social responsiveness). In Sethi's schema, social obligation is "corporate behavior in response to market forces or legal constraints"; social responsibility implies "bringing corporate behavior up to a level where it is congruent with the prevailing social norms, values, and expectations of performance"; and social responsiveness, which focuses on a corporation's long-run role in a dynamic social system, requires corporations "to anticipate the changes that are likely to take place in the system in the future" [29] (pp. 60-63). This perspective was strengthened by Archie B. Carroll, one of the discipline's most prestigious scholars. In 1979, Carroll developed the three-dimensional conceptual model of CSP that includes the integration of CSR, social responsiveness, and social issues [15]. He also proposed a four-part definition of CSR: "The social responsibility of business encompasses the economic, legal, ethical, and discretionary expectations that society has of organizations at a given point in time" [15] (p. 500).

Carroll later in 1991 enunciated this position by proposing the 'Pyramid of CSR', constituting four components: economic, legal, ethical, and philanthropic [30]. The economic component of the definition, in line with the capitalistic economic view, suggests that society expects corporations to make a profit. Legal responsibility suggests that corporations are expected to abide by laws established by the society's legal system. Ethical and discretionary/philanthropic components of the definition suggest a responsibility that extends beyond meeting minimum legal standards. Ethical responsibility mainly refers to corporate voluntary actions, as expected or prohibited by societal members, to promote those social goals that are beyond immediate corporate financial interest. Discretionary/philanthropic responsibility also includes a broad scope of corporate voluntary activities in response to various societal expectations, such as corporate contributions of financial resources or executive time to various causes (e.g., education, community improvement, arts and culture) [15,30].

This three-dimensional integration of responsibility, responsiveness, and social issues by Carrol [15] was furthered developed by other scholars. Wartick and Cochran [31] extended the CSP model by recasting the three aspects of CSR, social responsiveness, and social issues into a framework of principles, processes, and policies. Furthermore, Wood [32] built on the work of Carroll [15] and Wartick and Cochran [31] and explained three facets of the CSP model in detail: (1) 'principles of CSR' at the three levels of institutional, organizational, and individual; (2) 'processes of responsiveness' including environmental assessment, stakeholder management, and issues management; and (3) 'policies' developed by corporations to address social issues as the final outcome of corporate behavior motivated by principles and occurring through processes. Although the CSP model clearly advanced the CSR literature, it was not able to gain widespread application due to the lack of capacity to measure and empirically test the model [22]. 
The 1980s and 1990s witnessed a continued shift within the CSR literature away from an ethics orientation to a performance orientation, and from a macro level to a micro level (i.e., the corporate level) [13]. Several theories of the firm, such as stakeholder theory, resource-based theory, and institutional theory, have been incorporated into CSR within business literature to underpin CSR activities of corporations. By the mid-1980s, the role of stakeholders was found to be significant in influencing corporate performance around CSR. In 1984, Edward R. Freeman articulated how the inclusion of stakeholders, defined as "any group or individual who can affect or is affected by the achievement of the organization's objectives", in strategic management can mitigate corporate risk [33] (p. 46). Stakeholder theory was later expanded by Donaldson and Preston [34] who distinguished three branches of the theory: (1) descriptive (how corporations behave), (2) normative (how corporations should behave), and (3) instrumental (how behavior affects corporate performance).

Concerning CSR and a corporation's relationships with its multi-stakeholders, Clarkson [35] explained that a corporation that cultivates relationships with its primary stakeholders (e.g., shareholders, investors, employees, customers, suppliers, governments, communities) and meets their needs and expectations through CSR creates more value. Snider et al. [36] investigated what firms communicate to various stakeholders in relation to their CSR actions and stressed the importance of the linkage between CSR and corporate relations to its stakeholders in creating values. Other studies also discussed the importance of stakeholder influence in making a business case for CSR [37]. Stakeholder theory provides a base for understanding the actions of corporations necessary to carry out their missions with respect to the multi-stakeholders with whom they interact and hold responsibilities [38]. Since the 1990s, the emphasis of CSR has been on the responsibilities of a corporation to create value for both its shareholders and its various stakeholders, such as government agencies, customers, employees, and local communities. The similar objectives of CSR and stakeholder theory, such as value creation and effective stakeholder management, have allowed the two to coexist and to incorporate each other yet thrive independently [39].

Resource-based theory, the notion of achieving competitive advantage through the deployment of specific corporate resources, gained substantial attention in the 1980s through notable contributions such as those of Rumelt [40] and Wernerfelt [41]. The idea was heavily influenced by the earlier work of Edith T. Penrose [42] who described a corporation as 'a bundle of resources'. The theory was later refined by Jay Barney [43], who suggested that "sources of sustained competitive advantage are firm resources that are valuable, rare, imperfectly imitable, and non-substitutable" (p. 116). Similarly, Peteraf [44] discussed a heterogeneity which reflects the presence of superior resources that enable organizations to gain a competitive advantage. A basic assumption within resource-based theory is that corporations have heterogeneous resource endowments, and therefore can use their resources to identify and employ those assets, capabilities, organizational processes, and competencies that improve their efficiency and effectiveness to deliver superior competitive advantage.

Several studies have attempted to identify CSR actions and attribute them to resource-based theory as corporate resources. Litz [45] studied the integration of resource-based theory into CSR through inclusion of social and ethical perspectives; the conclusion was that social and ethical competencies have potential in facilitating the development of necessary corporate capabilities to lead to competitive advantage. Branco and Rodrigues [46] also discussed the usefulness of resource-based theory in understanding why corporations engage in CSR. They emphasized the importance of investing in CSR to create intangible resources, such as improved reputation, improved corporate relations with external stakeholders, increased retention and corporate attractiveness to prospective employees, and increased employee motivation in role performance, commitment and loyalty [46]. This positions CSR as a dynamic intangible resource within resource-based theory, focusing on creating and maintaining a competitive advantage for corporations.

Another theory linked to CSR is institutional theory. First conceptualized by Philip Selznick [47], and further supported by Meyer and Rowen [48], institutional theory proposes the idea that "organizations are driven to incorporate the practices and procedures defined by prevailing rationalized 
concepts of organizational work and institutionalized in society. Organizations that do so increase their legitimacy and their survival prospects, independent of the immediate efficacy of the acquired practices and procedures" (p. 340). Its foundation holds forth that corporate survival is significantly improved by demonstrations of conformity to the norms and social expectations within which the corporation operates. This corporate conformity brings a variety of rewards, such as increased prestige, stability, legitimacy, social support, internal and external commitment, attraction of personnel, and acceptance in professions [49]. DiMaggio and Powell [50] built on the theory and described the three institutional views of isomorphism processes as coercive, mimetic, and normative, which lead to homogeneity in the structure, culture, and output of organizations; this is the focus of the new institutionalism (or neo-institutionalism).

Several studies have applied institutional theory to understand why CSR activities vary among different organizations in different geographical locations [51-53]. These researchers suggest taking into account institutional constituents-including historical, political, and cultural determinants-for CSR engagement as corporations face greater rational pressures to adopt CSR to legitimate their activities when stakeholders are empowered by these institutions. Shabana et al. [54], drawing from DiMaggio and Powell's model, also discuss how isomorphism mechanisms have shaped CSR reporting practices over time, such that isomorphism is at work in each stage, but the underlying dynamics vary; initially driven by coercive isomorphism, then normative isomorphism, and finally mimetic isomorphism.

By the end of the 1990s, CSR researchers were integrating a focus on a tighter coupling between the economic and social performance of corporations. Griffin and Mahon [55] studied the CSP and corporate financial performance (CFP) relationship and concluded a positive relationship between the two. Waddock and Graves [56] used an empirical analysis to evaluate the linkage between CSP and CFP and also reported a positive association. Margolis and Walsh [57] found that "there is a positive association, and certainly very little evidence of a negative association, between a company's social performance and its financial performance" (p. 277). The meta-analysis of 52 studies by Orlitzky et al. [58] also suggests a positive relationship between CSP and CFP. Moreover, the inclusion of environmental aspects of corporations into CSR gained more widespread recognition during this period. Environmental aspects of corporate activities indeed gained increased salience with the articulation of 'sustainable development', conceptualized by the World Commission on Environment and Development (WCED) report, Our Common Future (also known as the Brundtland Commission Report) [59]. Sustainable development was explicitly linked to corporate activities and CSR with the introduction of the triple bottom line in the late 1990s by John Elkington. The triple bottom line directs corporate responsibility by placing emphasis on 'the simultaneous pursuit of economic prosperity, environmental quality and social equity' [60]. CSR subsequently started to embrace the environmental aspects more actively, so that the European Commission [61] defined CSR as being "about companies having responsibilities and taking actions beyond their legal obligations and economic/business aims. These wider responsibilities cover a range of areas but are frequently summed up as social and environmental where social means society broadly defined, rather than simply social policy issues. This can be summed up as the 'triple bottom line approach: i.e., economic, social and environmental'" (p. 1).

Despite the abundant research, there is yet to be a common definition for CSR [53]. Frederick [12] states that "the content or substance-the operational meaning-of corporate social responsibility is supremely vague" (p. 38). Regardless of the ambiguity, there are some consistencies among the many CSR definitions. Dahlsrud [62], who identified and analyzed 37 definitions of CSR from 1980 to 2003, concludes that "the definitions are predominantly congruent" (p. 6). He also found the most frequently reported dimensions of CSR to be stakeholder, social, economic, voluntariness, and environmental dimensions [62]. Sarkar and Searcy [63] also analyzed 110 definitions of CSR from both peer-reviewed and gray literature published between 1953 and 2014, and found six similar dimensions: stakeholder, social, economic, ethical, sustainability, and discretionary. 
The last two decades have been a productive time for CSR scholarly publications; over $40 \%$ of CSR articles have been published since 2005 [64]. Moreover, since 2000, CSR has been coupled with strategy literature and focused on promoting corporate responsibility towards a wide range of stakeholder groups, including shareholders, civil society and the environment. The contemporary CSR reflects corporate responsibility towards different stakeholders with respect to the triple bottom line of economic, social, and environmental performance [64]. Creating shared value (i.e., shareholders' value and stakeholders' value) has also become an integral part of the contemporary CSR [38,65].

There are other competing and complementary concepts, such as business ethics, corporate citizenship, and CS, which have been extensively studied by scholars [66]. All have received increasing attention as potential guidelines for corporations to effectively plan and implement strategies to drive their transformation and sustained growth while ensuring the continuity of benefits to society and the environment [67]. Notwithstanding that these concepts have largely been incorporated in CSR, each has its own body of literature which is beyond the scope of this study. In the following section, CS - the most widely used interchangeable term for CSR—and the related sustainable development terminology are discussed in detail.

\section{CS and Theories of the Firm}

The root of CS can be traced to the late 1980s when the concept of sustainable development was gaining traction [66]. The definition of CS is adopted from the concept of sustainable development and can be understood as the application of sustainable development at the corporate level, including the short-term and long-term economic, environmental, and social aspects of a corporation's performance $[2,4,68-70]$.

The concept of sustainable development itself was derived from the word 'sustainability' first used in 1972 in the context of man's future in the British book, Blueprint for Survival, and first used by the United Nations (UN) in 1978 in the context of 'eco-development' [71]. It grew out of the environmental movements [72], but it has since been extended to include all three dimensions of economy, society, and the environment [66,73-75]. The debate over environmental protection (conservation/preservation) goes back to the 19th century, but it was at the end of the 20th century that mainstreaming of environmental considerations as necessary for the survival of societies gained greater salience through the emergence of 'sustainable devolvement', resulting in numerous publications aimed at providing guidance for transition to sustainable development [76]. One example is the World Conservation Strategy, published in 1991, which shifted the focus from primarily being on ecological issues, published in 1981, toward achieving sustainable development through the inclusion of both the environment and human dimensions [76]. In between these two reports, the WCED published the Brundtland Commission Report.

The WCED [59] encouraged development that could bridge the gap between environmental and social concerns regarding increasing impacts of human activities, and sustainable economic growth. Sustainable development was defined as "development that meets the needs of the present without compromising the ability of future generations to meet their own needs" (p. 41). Many others have attempted to define sustainable development as the definition proposed by the Brundtland Commission Report was found to be ambiguous and open to confusion, and ineffective in its action-guiding role [77]. By 1992, there were at least 70 different definitions for sustainable development [78]; this increased to over 300 by 2007 [79]. Notwithstanding the many definitions of sustainable development and the ongoing discourse [75], the Brundtland Commission Report has contributed to conceptualizing the concept and forcing it to the top of the agenda of the UN and other multilateral organizations [80]. This is perhaps due to the central messages the Report conveys: (1) integrating the social dimension with the environmental dimension in promoting economic development; (2) integrating the three dimensions of social, environmental, and economic across all sectors and interests through partnership; and (3) integrating the spatial dimension [76].

Since the early 1990s, researchers have sought to better understand the benefits of sustainable development to the corporation and determine how best to incorporate the concept (mainly the 
environmental dimension) into corporations. The central focus on environment could be attributed to the historical under-representation of environmental considerations within business strategy [81]. Many researchers attempted to understand the benefits of incorporating environmental considerations into business decisions using theories of the firm, such as resource-based theory, stakeholder theory and institutional theory. Hart [82] was the first to apply environmental strategies to resource-based theory; he asserted that certain environmental strategies could constitute a resource or a capability that can lead to firm's competitive advantage. Hart [83] continued his argument about the potential for sustainable development strategies to confer competitive advantage, concluding that the environmental dimension of sustainability might become a major source of revenue growth and competitive advantage if it is linked to strategy or technology development. On that note, Shrivastava [84] called for the inclusion of environmental technologies in strategic management for corporations to gain competitive advantage. Many others have offered support for Hart's [82] argument. Judge and Douglas [85] empirically examined the effects of integrating the environment into resource-based theory and concluded that there is a positive relationship between the level of integration of environmental issues into the strategic planning process and CFP. Sharma and Vredenburg [86] examined the applicability of resource-based theory within the domain of environmental responsiveness and concluded that proactive environmental strategies within the corporation are linked to unique competitively valuable capabilities. Such studies reveal that the incorporation of environmental considerations into business strategies and operations may lead to competitive advantage as resource-based theory suggests.

Concurrently, other researchers sought to apply stakeholder theory to sustainable development-related research, such as developing environmental marketing strategy [87], pro-environmental responses in different corporations [88], and inclusion of the environment as a stakeholder entity [89-91]. Buysse and Verbeke [92] studied linkages between environmental strategies and stakeholder management through surveying 197 firms in Belgium, arguing that environmental leadership, in addition to resource allocation, is associated with a long-term vision to broaden and deepen linkages between corporations and multi-stakeholders. This aligns with stakeholder theory, which suggests that when corporations meet the needs and expectations of their stakeholders, they are capable of creating greater value over time [33]. Stakeholders' engagement also influences the sustainability performance of corporations by generating knowledge that can help identify potential process innovations. For example, Sharma and Henrique [93] studied stakeholder influence on the sustainability performance of the Canadian forestry industry and reported a strong correlation between meaningful stakeholder engagement and the sustainability performance of firms.

Researchers have also sought to integrate institutional theory into sustainable development research. Although institutional theory emerged in the late 1970s [48], its integration into the sustainable development field appeared in the 1990s. Jennings and Zandbergen [94] studied the use of institutional theory as an approach to sustainable development to understand both how consensus is built around the meaning of sustainability and the ways in which sustainability practices are developed and implemented by corporations. Other studies also focused on the use of institutional theory to analyze the adoption of environmental actions and policies by corporations [95,96]. Bansal and Clelland [97] applied institutional theory to understand the relationship between a corporation's environmental legitimacy and its level of unsystematic risk and found that environmentally legitimate corporations incur less unsystematic risk. Bansal [98] provided further insights through combining institutional theory and resource-based theory and concluded that the two theories influence sustainable development. So, organizations facing institutional pressures (e.g., media attention, scrutiny from activists, and community concerns) could gain legitimacy through exhibiting good sustainability performance. Institutional pressures influencing organizational legitimacy could also go beyond those of domestic markets and come from other regions and countries. On that note, a recent study by Park [99] found that internationalization drives CS strengths and concerns in emerging markets' economies. 
Since the 2000s, the use of the term 'corporate sustainability' has become widespread [1,4,5,68,100-102]. One of the earliest and most cited definitions of CS is associated with the work of Dyllick and Hockerts [100], who defined CS as "meeting the needs of a firm's direct and indirect stakeholders (such as shareholders, employees, clients, pressure groups, and communities), without compromising its ability to meet the needs of future stakeholders as well" (p. 131). Looking at the trend in the CS literature, one could surmise that the field of CS is still evolving [6]. Nonetheless, the definition of CS benefits from having roots in the concept of sustainable development, and therefore, there exists less inconsistency among scholars on what CS means [103]. CS encompasses the inclusion of the short-term and long-term economic, environmental, and social aspects of a corporation's performance $[4,69,70]$. It also seeks to create long-lasting shareholders' and stakeholders' values for corporations [2].

There is consensus among scholars and practitioners that sustainable development at the societal level will require CS being incorporated as a core into corporate business strategies, but the notion that the business model is the key for initiating CS components has only recently gained increased attention. Schaltegger et al. [104] recognized a business model for sustainability as one that "helps describing, analyzing, managing, and communicating (i) a company's sustainable value proposition to its customers, and all other stakeholders, (ii) how it creates and delivers this value, (iii) and how it captures economic value while maintaining or regenerating natural, social, and economic capital beyond its organizational boundaries" (p. 6). Several studies have explored how embedding sustainability into a corporate business model can improve economic viability while reducing negative effects or creating positive effects for society and the environment [105-109]. These researchers suggest the integration of social and environmental aspects into the economic-centered view of a standard business model through an innovation process to create value and competitive advantage. They also emphasize developing internal structural and cultural capabilities, while collaborating with key stakeholders, as necessary conditions for a sustainability-oriented business model. Researchers further highlight that there is no 'one-size-fit-all' business model for sustainability, and the on-going creation of business cases for sustainability is imperative. Nonetheless, recent literature stresses the need to broaden the current narrowly conceived CS. It must extend beyond the business case and shed light on developing new models that can help corporations understand the paradigm shift necessary to move towards sustainable development $[2,67]$. There has also been an emphasis on identifying driving factors for corporations to more earnestly adopt CS and advance pragmatic sustainability solutions and initiatives [67]. This includes investigating different levels of CS sophistication exhibited by corporations with respect to their social, environmental, and economic performance, as well as evaluating multi-stakeholder partnerships and synergies benefiting CS [110].

\section{Integrative Theoretical Framework for CSR and CS}

The literature includes many examples where temporality is explicitly expressed as part of the sustainable development or CS definitions [1,4,65,78,111]; however, temporal aspects of corporate activities have not been a core idea of CSR [8]. Regardless of the differences that exist among these concepts, they have all become an integral part of business discussion [13]. In fact, identifying, managing, measuring, and reporting social, environmental, and economic elements of corporate impacts on, responsibilities to, and relationships with different stakeholder groups are the basis upon which each notion is operationalized. The fundamental idea embedded in the contemporary CSR and CS notions is that businesses, in addition to focusing on profits, have an obligation to foster social and environmental stewardship. Different theories of the firm have been applied in business responsibility and sustainability $[4,65,112]$, among which institutional, resource-based, and stakeholder theories are discussed in this study as a rationale for profound ethical, scientific, and practical decisions on CSR and CS, and for driving potential improvements in CSR and CS implementation. Figure 2 summarizes the evolution of CSR and CS from their early emergence and the main contributors to the understanding of the fields. It also highlights the tipping point in the implications of resource-based theory, institutional 
theory, and stakeholder theory in the context of CSR and CS (the mid-1990s), which is when the literature began to emphasize the use of these three theories in CSR and CS studies.

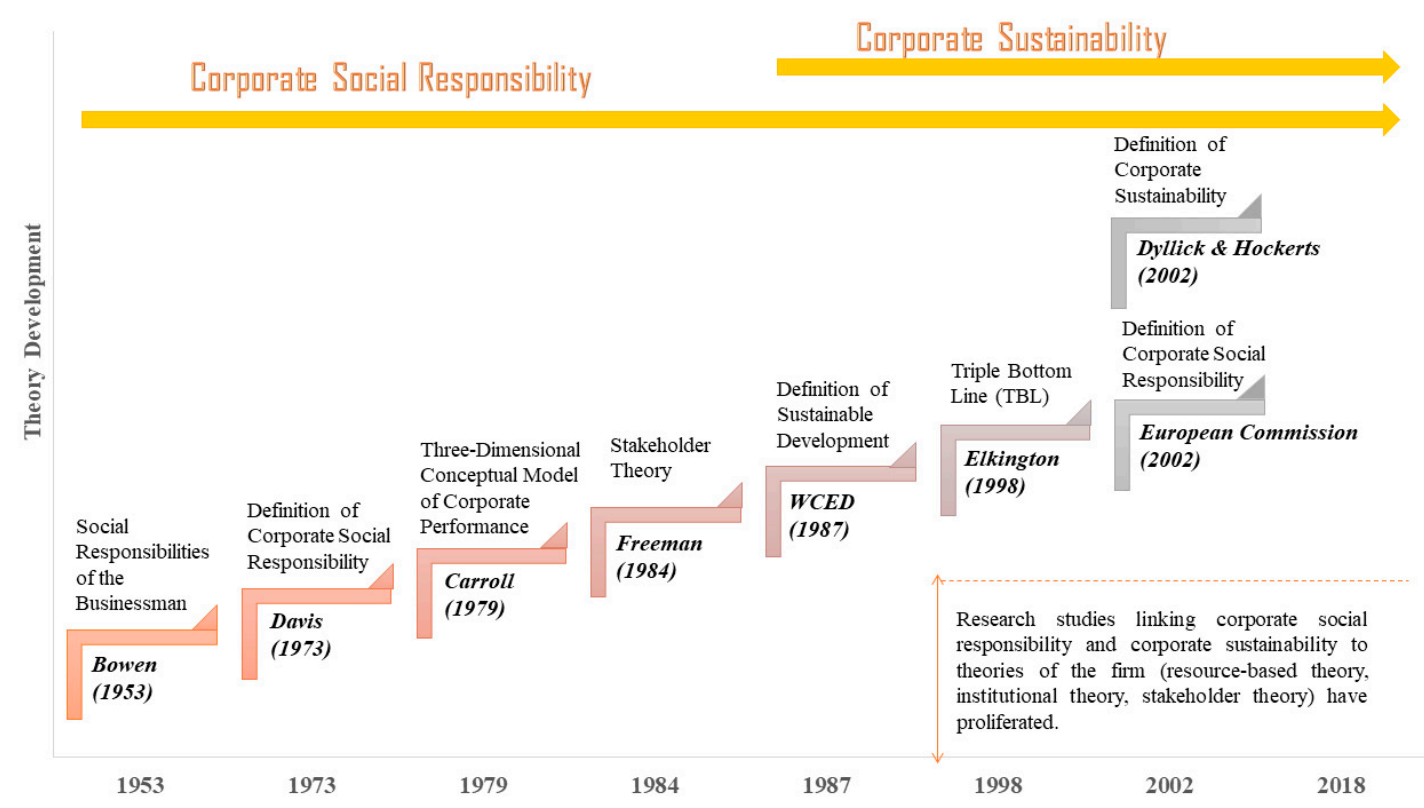

Figure 2. Chronology of developmental and evolutionary sequences in corporate social responsibility and corporate sustainability.

The implications of resource-based theory, institutional theory, and stakeholder theory for CSR and CS can be grounded in an integrative theoretical framework (Figure 3). The framework posits that corporate choice of CSR and CS actions and policies is supported by dual driving forces; internal, based on resource-based theory, and external, based on institutional theory. This is to meet the interests and expectations of internal and external stakeholders, the basis upon which stakeholder theory is constructed. The integrative theoretical framework suggests that the three theories of resource-based, institutional, and stakeholder could be used as the primary step in explaining corporate recognition of the need for CSR and CS. It further suggests that these theories of the firm could also be used to promote the identification, development and inclusion of different CSR and CS actions and policies.

Both resource-based theory and institutional theory play a dominant role in CSR and CS research to understand whether, and under which conditions, superior CSR or CS performance will lead to superior competitive advantage and societal values [4]. Resource-based theory and institutional theory, indeed, offer complementary explanations for why and how corporations make strategic choices to respond to their environment [113]. Resource-based theory suggests that a corporation's competitive advantage can be achieved by leveraging those internal resources that are valuable, rare, non-substitutable, and not easily imitated by rivals [43]. Therefore, heterogeneity in resource-based theory accounts for the generation of competitive advantage [44]. The theory also stresses that corporate decisions about resource selection are mainly based on the economic rationale within the constraints of limited information, cognitive biases, and causal ambiguity [114]. According to this perspective, corporations adopt CSR and CS policies and actions contingent on corporate power and control over their distinctive internal resources and capabilities (e.g., reputation, in-house knowledge of technology, employment of skilled personnel, trade contacts, equipment, efficient procedures, and capital) to sustain their competitive advantage [41]. Institutional theory, on the other hand, explains non-choice behaviour of corporations constrained by social judgement, historical limitations, and the inertial force of habit [114]. It proposes that corporate strategic choices are based on institutional isomorphic pressures exerted by the social environment, such as cultural norms, symbols, beliefs, and rituals [115]. There is no obvious economic or technical justification; conformity to social expectations is what contributes to corporate success and survival [114]. Based on this perspective, corporate adoption 
of CSR and CS strategies might not be driven by profit-making interest nor be entirely economically justified; instead, such actions are largely induced by preconscious acceptance of institutionalized values and practices [49]. The compatibility of institutional theory with resource-based theory can be perceived through recognizing the importance of the social context in addition to the economic context for corporate survival and success. While the former fulfills the interests and expectations of a broad set of stakeholder groups, which have traditionally included regulatory and governmental agencies, professional associations, interest groups, and public opinion [116], the latter primarily fulfills the interests and goals of a more limited set of stakeholders (e.g., shareholders) in gaining competitive advantage through corporate distinctive internal resources and capabilities.

The inclusion of stakeholder theory, which implies the importance of creating value for all stakeholders, both internal and external [33], as well as primary and secondary stakeholders [35], has provided a greater foundation for shaping CSR- and CS-driven policies and actions. According to this perspective, corporations adopt CSR and CS strategies for both normative, including moral and philosophical principles (e.g., fairness, environmentalism), and instrumental, including connections between stakeholder approaches and corporate desired objectives (e.g., profitability), value of consideration of multi-stakeholders' interests and the establishment of good relations with different stakeholder groups $[39,117]$. Stakeholder theory provides a foundation for the establishment and development of corporate management, operational, and stewardship plans to meet the interests and expectations of all relevant stakeholders [118]. In essence, integrating the descriptive, normative, and instrumental aspects of stakeholder theory can contribute to creating shared values, which helps to drive and maintain stakeholder relationships [117]. This is in line with creating a shared value goal of contemporary CSR and CS, upon which they are based [8]. The shared value-creating aspects of CSR and CS are conclusive only when CSR and CS relate to the core business model of a corporation and do not just comprise afterthought or add-on activities [119].

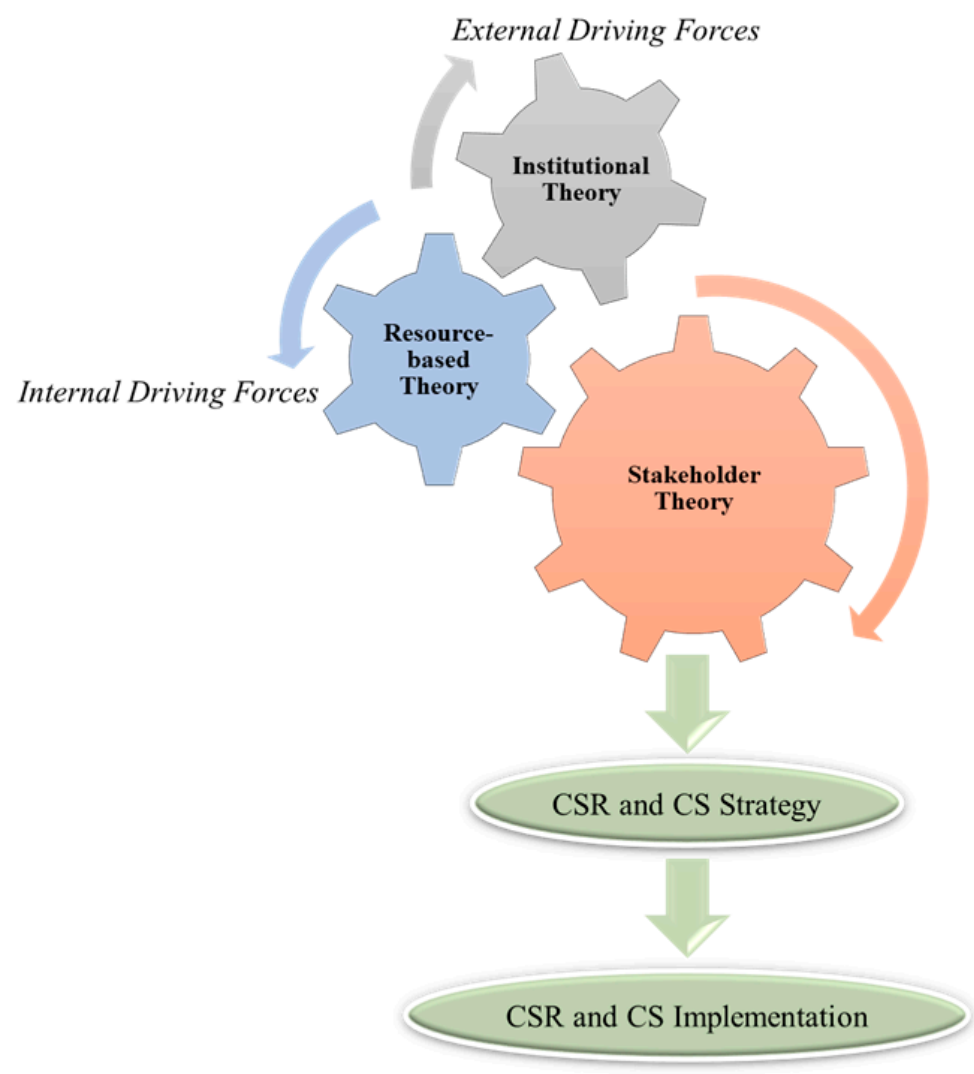

Figure 3. Integrative theoretical framework underpinning corporate social responsibility and corporate sustainability. 
In general, the actions and influence of stakeholders affect whether corporations choose to engage in CSR and CS, as well as the types of actions pursued [120]. A greater influence exists when stakeholders are seen to have more power and legitimacy [66]. To this end, the notion of 'stakeholder salience' helps us understand how corporations manage their stakeholder relationships; corporate resource allocation is performed primarily for stakeholders with high salience (i.e., those with the highest levels of power, legitimacy, and urgency) [121]. The management of competing stakeholder interests, however, requires corporations to recognize "the overall stakeholder relationship as a multifaceted, multiobjective, complex phenomenon" [122] (p. 484). Corporations are therefore expected to go beyond the traditional logic of stakeholder salience, and to identify and engage 'fringe' stakeholders (i.e., those that are perceived to be non-legitimate, non-urgent, and powerless-even non-human) [123]. This helps corporations to identify the unit of analysis, beyond the corporation itself, based on their relationships with a broader group of stakeholders [119] in order to manage disruptive changes and to create new, distinctive ideas shaping the future of business.

\section{Academic and Managerial Implications}

This study adds value to the academic research by following the developmental and evolutionary sequences in business responsibility and sustainability, while contemplating the connections between CSR and CS through the lens of the dominant theoretical perspectives underpinning the concepts. It enables young CSR/CS scholars, in particular, as well as researchers outside the fields to comprehend how CSR and CS are conceptualized and operationalized through theoretical developments. It also provides directions towards using an integrated view for CSR and CS studies, rather than an individual internal view or external view. This study also has managerial implications. It helps managers to comprehend clearly the need to integrate CSR and CS into strategic business decisions and operation processes to enable their corporations to successfully manage competing issues, and to effectively take the lead in their sector by devising and implementing sustainability and responsibility initiatives. Such integration is explained based on resource-based theory, institutional theory, and stakeholder theory, focusing on corporate distinctive internal resources and capabilities, preconscious acceptance of institutionalized values and practices, and finally consideration of different stakeholder groups when defining corporate values to help corporations to autonomously analyze the conditions under which CSR and CS strategies are formulated, and to predict the ramifications of those strategies once implemented.

\section{Study Limitations and Suggestions for Future Research}

We reviewed the CSR and CS literature, focusing mainly on primary studies in top management journals. While we attempted to expand our review from as early as 1950 to current trends to address the research objective, we acknowledge that we have not included all studies on CSR and CS within this time frame, nor used a systematic temporal approach, but have rather reviewed relevant articles by following the developmental and evolutionary sequences in business sustainability and responsibility. This is, of course, due to the CSR and CS literature being vast and widely scattered in different disciplines, and thus a major limitation for this narrative review. As much as we sought all relevant, primary studies on CSR and CS, we believe that there may be other studies that could be possibly included to complement the discussion on contributions of resource-based, institutional, and stakeholder theories in the context of CSR and CS. Such a limitation, while presumably unavoidable for a narrative review, may be circumvented in a systematic review. Future studies could expand this review and explore contributions of different theories of the firm in the context of CSR and CS through a systematic review approach. Moreover, while future studies could continue to explore the complex interrelationships between corporate strategy and their implications for social, environmental, and economic sustainability using the integrative theoretical framework, there is also potential in the use of other theories, including legitimacy theory, to evaluate how CSR and CS leadership priorities are impacted. Given that stakeholder theory can play a compelling role in CSR and CS research, future 
works could examine factors influencing corporate choice of CSR and CS interplaying the internal and external, or those of primary and secondary stakeholders, to better understand how corporations could craft a business plan that is able to manage conflicting strategic imperatives. Best industry-specific practices related to CSR and CS strategies should also be investigated based on a multi-stakeholder perspective to contribute to the adoption of a corporate business model with a clear focus on delivering sustained values for all stakeholders.

Author Contributions: Writing—original draft preparation, M.A.; Writing—review and editing, M.A., G.M.M., M.A., and T.R.W.; Supervision, G.M.M., M.A., and T.R.W. All authors have read and agreed to the published version of the manuscript.

Funding: This research received no external funding.

Conflicts of Interest: No potential conflict of interest was reported by the authors.

\section{References}

1. Vermeulen, W.J.; Witjes, S. On addressing the dual and embedded nature of business and the route towards corporate sustainability. J. Clean. Prod. 2016, 112, 2822-2832. [CrossRef]

2. Dyllick, T.; Muff, K. Clarifying the meaning of sustainable business: Introducing a typology from business-as-usual to true business sustainability. Organ. Environ. 2016, 29, 156-174. [CrossRef]

3. Lozano, R. A holistic perspective on corporate sustainability drivers. Corp. Soc. Responsib. Environ. Manag. 2015, 22, 32-44. [CrossRef]

4. Hahn, T.; Figge, F.; Aragón-Correa, J.A.; Sharma, S. Advancing research on corporate sustainability: Off to pastures new or back to the roots? Bus. Soc. 2017, 56, 155-185. [CrossRef]

5. Montiel, I. Corporate social responsibility and corporate sustainability: Separate pasts, common futures. Organ. Environ. 2008, 21, 245-269. [CrossRef]

6. Montiel, I.; Delgado-Ceballos, J. Defining and measuring corporate sustainability: Are we there yet? Organ. Environ. 2014, 27, 113-139. [CrossRef]

7. Bansal, P.; Song, H.-C. Similar but not the same: Differentiating corporate sustainability from corporate responsibility. Acad. Manag. Ann. 2017, 11, 105-149. [CrossRef]

8. Ashrafi, M.; Adams, M.; Walker, T.R.; Magnan, G. How corporate social responsibility can be integrated into corporate sustainability: A theoretical review of their relationships. Int. J. Sustain. Dev. World Ecol. 2018, 25, 672-682. [CrossRef]

9. Abad-Segura, E.; Cortés-García, F.J.; Belmonte-Ureña, L.J. The Sustainable Approach to Corporate Social Responsibility: A Global Analysis and Future Trends. Sustainability 2019, 11, 5382. [CrossRef]

10. Seth, A.; Thomas, H. Theories of the firm: Implications for strategy research. J. Manag. Stud. 1994, 31, 165-192. [CrossRef]

11. Starik, M.; Kanashiro, P. Toward a theory of sustainability management: Uncovering and integrating the nearly obvious. Organ. Environ. 2013, 26, 7-30. [CrossRef]

12. Frederick, W.C. Corporation, be Good! The Story of Corporate Social Responsibility; Dog Ear Publishing: Indianapolis, IN, USA, 2006.

13. Carroll, A.B.; Shabana, K.M. The business case for corporate social responsibility: A review of concepts, research and practice. Int. J. Manag. Rev. 2010, 12, 85-105. [CrossRef]

14. Abrams, F.W. Management's responsibilities in a complex world. Harv. Bus. Rev. 1951, 29, $29-34$.

15. Carroll, A.B. A Three-Dimensional Conceptual Model of Corporate Performance. Acad. Manag. Rev. 1979, 4, 497-505. [CrossRef]

16. Bowen, H.R. Social Responsibility of the Businessman; Harper: New York, NY, USA, 1953.

17. Frederick, W.C. The growing concern over business responsibility. Calif. Manag. Rev. 1960, 2, 54-61. [CrossRef]

18. Levitt, T. The dangers of social-responsibility. Harv. Bus. Rev. 1958, 36, 41-50.

19. Friedman, M. Capitalism and Freedom; The University of Chicago Press: Chicago, IL, USA, 1962.

20. Friedman, M. The Social Responsibility of Business is to Increase its Profits. N. Y. Times Mag. 1970, $122-126$. 
21. Wallich, H.C.; McGowan, J.J. Stockholder interest and the corporation's role in social policy. In A New Rationale for Corporate Social Policy; Baumol, W.J., Likert, R., Wallich, H.C., McGowan, J.J., Eds.; Committee for Economic Development: New York, NY, USA, 1970; pp. 39-59.

22. Lee, M.D.P. A review of the theories of corporate social responsibility: Its evolutionary path and the road ahead. Int. J. Manag. Rev. 2008, 10, 53-73. [CrossRef]

23. Davis, K. The case for and against business assumption of social responsibilities. Acad. Manag. J. 1973, 16, 312-322.

24. Baumol, W.J. Enlightened self-interest and corporate philanthropy. In A New Rationale for Corporate Social Policy; Committee for Economic Development: New York, NY, USA, 1970; pp. 3-19.

25. Committee for Economic Development (CED). Social Responsibilities of Business Corporations; CED: New York, NY, USA, 1971.

26. Moyer, R.C. Efficiency and corporate social investment. Bus. Soc. 1974, 14, 5-11. [CrossRef]

27. Ackerman, R.W. How companies respond to social demands. Harv. Bus. Rev. 1973, 51, 88-98.

28. Frederick, W.C. From CSR1 to CSR2: The maturing of business-and-society thought. Bus. Soc. 1994, 33, 150-164. [CrossRef]

29. Sethi, S.P. Dimensions of corporate social performance: An analytical framework. Calif. Manag. Rev. 1975, 17, 58-64. [CrossRef]

30. Carroll, A.B. The pyramid of corporate social responsibility: Toward the moral management of organizational stakeholders. Bus. Horiz. 1991, 34, 39-48. [CrossRef]

31. Wartick, S.L.; Cochran, P.L. The evolution of the corporate social performance model. Acad. Manag. Rev. 1985, 10, 758-769. [CrossRef]

32. Wood, D.J. Corporate social performance revisited. Acad. Manag. Rev. 1991, 16, 691-718. [CrossRef]

33. Freeman, E.R. Strategic Management: A Stakeholder Approach; Harpercollins College Div: Pitman, MA, USA, 1984.

34. Donaldson, T.; Preston, L.E. The stakeholder theory of the corporation: Concepts, evidence, and implications. Acad. Manag. Rev. 1995, 20, 65-91. [CrossRef]

35. Clarkson, M.E. A stakeholder framework for analyzing and evaluating corporate social performance. Acad. Manag. Rev. 1995, 20, 92-117. [CrossRef]

36. Snider, J.; Hill, R.P.; Martin, D. Corporate social responsibility in the 21st century: A view from the world's most successful firms. J. Bus. Ethics 2003, 48, 175-187. [CrossRef]

37. Barnett, M.L. Stakeholder influence capacity and the variability of financial returns to corporate social responsibility. Acad. Manag. Rev. 2007, 32, 794-816. [CrossRef]

38. Carroll, A.B. Corporate social responsibility: The centerpiece of competing and complementary frameworks. Organ. Dyn. 2015, 44, 87-96. [CrossRef]

39. Freeman, R.E.; Dmytriyev, S. Corporate social responsibility and stakeholder theory: Learning from each other. Symph. Emerg. Issues Manag. 2017, 1, 7-15.

40. Rumelt, R.P. Toward a Strategic Theory of the Firm. In Competitive Strategic Management; Lamb, R., Ed.; Prentice Hall: Upper Saddle River, NJ, USA, 1984; pp. 556-570.

41. Wernerfelt, B. A resource-based view of the firm. Strateg. Manag. J. 1984, 5, 171-180. [CrossRef]

42. Penrose, E.T. The Theory of the Growth of the Firm; Basil Blackwell: Oxford, UK, 1959.

43. Barney, J. Firm resources and sustained competitive advantage. J. Manag. 1991, 17, 99-120. [CrossRef]

44. Peteraf, M.A. The cornerstones of competitive advantage: A resource-based view. Strateg. Manag. J. 1993, 14, 179-191. [CrossRef]

45. Litz, R.A. A resource-based-view of the socially responsible firm: Stakeholder interdependence, ethical awareness, and issue responsiveness as strategic assets. J. Bus. Ethics 1996, 15, 1355-1363. [CrossRef]

46. Branco, M.C.; Rodrigues, L.L. Corporate social responsibility and resource-based perspectives. J. Bus. Ethics 2006, 69, 111-132. [CrossRef]

47. Selznick, P. Foundations of the theory of organization. Am. Sociol. Rev. 1948, 13, 25-35. [CrossRef]

48. Meyer, J.W.; Rowan, B. Institutionalized organizations: Formal structure as myth and ceremony. Am. J. Sociol. 1977, 83, 340-363. [CrossRef]

49. Oliver, C. Strategic responses to institutional processes. Acad. Manag. Rev. 1991, 16, 145-179. [CrossRef]

50. DiMaggio, P.J.; Powell, W.W. The Iron Cage revisited: Institutional isomorphism and collective rationality in organizational fields. Am. Sociol. Rev. 1983, 48, 147-160. [CrossRef] 
51. Beliveau, B.; Cottrill, M.; O'Neill, H.M. Predicting corporate social responsiveness: A model drawn from three perspectives. J. Bus. Ethics 1994, 13, 731-738. [CrossRef]

52. Campbell, J.L. Why would corporations behave in socially responsible ways? An institutional theory of corporate social responsibility. Acad. Manag. Rev. 2007, 32, 946-967. [CrossRef]

53. Matten, D.; Moon, J. "Implicit" and "explicit" CSR: A conceptual framework for a comparative understanding of corporate social responsibility. Acad. Manag. Rev. 2008, 33, 404-424. [CrossRef]

54. Shabana, K.M.; Buchholtz, A.K.; Carroll, A.B. The institutionalization of corporate social responsibility reporting. Bus. Soc. 2017, 56, 1107-1135. [CrossRef]

55. Griffin, J.J.; Mahon, J.F. The corporate social performance and corporate financial performance debate: Twenty-five years of incomparable research. Bus. Soc. 1997, 36, 5-31. [CrossRef]

56. Waddock, S.A.; Graves, S.B. The corporate social performance-financial performance link. Strateg. Manag. J. 1997, 18, 303-319. [CrossRef]

57. Margolis, J.D.; Walsh, J.P. Misery loves companies: Rethinking social initiatives by business. Adm. Sci. Q. 2003, 48, 268-305. [CrossRef]

58. Orlitzky, M.; Schmidt, F.L.; Rynes, S.L. Corporate social and financial performance: A meta-analysis. Organ. Stud. 2003, 24, 403-441. [CrossRef]

59. World Commission on Environment and Development (WCED). Our Common Future; Oxford University Press: Oxford, UK, 1987.

60. Elkington, J. Cannibals with Forks: The Triple Bottom Line of Sustainability; New Society Publishers: Gabriola Island, BC, Canada, 1998.

61. European Commission. Corporate Social Responsibility Main Issues; Office for Official Publications of the European Communities: Brussels, Belgium, 2002.

62. Dahlsrud, A. How corporate social responsibility is defined: An analysis of 37 definitions. Corp. Soc. Responsib. Environ. Manag. 2008, 15, 1-13. [CrossRef]

63. Sarkar, S.; Searcy, C. Zeitgeist or chameleon? A quantitative analysis of CSR definitions. J. Clean. Prod. 2016, 135, 1423-1435. [CrossRef]

64. Aguinis, H.; Glavas, A. What we know and don't know about corporate social responsibility: A review and research agenda. J. Manag. 2012, 38, 932-968. [CrossRef]

65. Bansal, P.; DesJardine, M.R. Business sustainability: It is about time. Strateg. Organ. 2014, 12, 70-78. [CrossRef]

66. Schwartz, M.S.; Carroll, A.B. Integrating and unifying competing and complementary frameworks: The search for a common core in the business and society field. Bus. Soc. 2008, 47, 148-186. [CrossRef]

67. Landrum, N.E. Stages of corporate sustainability: Integrating the strong sustainability worldview. Organ. Environ. 2017, 31, 287-313. [CrossRef]

68. Steurer, R.; Langer, M.E.; Konrad, A.; Martinuzzi, A. Corporations, stakeholders and sustainable development I: A theoretical exploration of business-society relations. J. Bus. Ethics 2005, 61, 263-281. [CrossRef]

69. Baumgartner, R.J.; Ebner, D. Corporate sustainability strategies: Sustainability profiles and maturity levels. Sustain. Dev. 2010, 18, 76-89. [CrossRef]

70. Lozano, R. Addressing stakeholders and better contributing to sustainability through game theory. J. Corp. Citizsh. 2011, 43, 45-62. [CrossRef]

71. Kidd, C.V. The evolution of sustainability. J. Agric. Environ. Ethics 1992, 5, 1-26. [CrossRef]

72. Redclift, M. Sustainable development (1987-2005): An oxymoron comes of age. Sustain. Dev. 2005, 13, 212-227. [CrossRef]

73. Kaptein, M.; Wempe, J. Sustainability management: Balancing conflicting economic, environmental and social corporate responsibilities. J. Corp. Citizen. 2001, 2, 91-106.

74. Hahn, T.; Scheermesser, M. Approaches to corporate sustainability among German companies. Corp. Soc. Responsib. Environ. Manag. 2006, 13, 150-165. [CrossRef]

75. Poveda, C.A. The theory of dimensional balance of needs. Int. J. Sustain. Dev. World Ecol. 2017, 24, 97-119. [CrossRef]

76. Robinson, J. Squaring the circle? Some thoughts on the idea of sustainable development. Ecol. Econ. 2004, 48, 369-384. [CrossRef]

77. Christen, M.; Schmidt, S. A formal framework for conceptions of sustainability-a theoretical contribution to the discourse in sustainable development. Sustain. Dev. 2012, 20, 400-410. [CrossRef] 
78. Lozano, R. Envisioning sustainability three-dimensionally. J. Clean. Prod. 2008, 16, 1838-1846. [CrossRef]

79. Johnston, P.; Everard, M.; Santillo, D.; Robèrt, K.-H. Reclaiming the definition of sustainability. Environ. Sci. Pollut. Res. 2007, 14, 60-66.

80. Daly, H.E. Toward some operational principles of sustainable development. Ecol. Econ. 1990, 2, 1-6. [CrossRef]

81. Schaefer, A. Corporate sustainability-integrating environmental and social concerns? Corp. Soc. Responsib. Environ. Manag. 2004, 11, 179-187. [CrossRef]

82. Hart, S.L. A natural-resource-based view of the firm. Acad. Manag. Rev. 1995, 20, 986-1014. [CrossRef]

83. Hart, S.L. Beyond greening: Strategies for a sustainable world. Harv. Bus. Rev. 1997, 75, 66-77.

84. Shrivastava, P. Environmental technologies and competitive advantage. Strateg. Manag. J. 1995, 16, $183-200$. [CrossRef]

85. Judge, W.Q.; Douglas, T.J. Performance implications of incorporating natural environmental issues into the strategic planning process: An empirical assessment. J. Manag. Stud. 1998, 35, 241-262. [CrossRef]

86. Sharma, S.; Vredenburg, H. Proactive corporate environmental strategy and the development of competitively valuable organizational capabilities. Strateg. Manag. J. 1998, 19, 729-753. [CrossRef]

87. Polonsky, M.J. A stakeholder theory approach to designing environmental marketing strategy. J. Bus. Ind. Mark. 1995, 10, 29-46. [CrossRef]

88. Fineman, S.; Clarke, K. Green stakeholders: Industry interpretations and response. J. Manag. Stud. 1996, 33, 715-730. [CrossRef]

89. Starik, M. Should trees have managerial standing? Toward stakeholder status for nonhuman nature. J. Bus. Ethics 1995, 14, 207-217. [CrossRef]

90. Phillips, R.A.; Reichart, J. The environment as a stakeholder? A fairness-based approach. J. Bus. Ethics 2000, 23, 185-197. [CrossRef]

91. Driscoll, C.; Starik, M. The primordial stakeholder: Advancing the conceptual consideration of stakeholder status for the natural environment. J. Bus. Ethics 2004, 49, 55-73. [CrossRef]

92. Buysse, K.; Verbeke, A. Proactive environmental strategies: A stakeholder management perspective. Strateg. Manag. J. 2003, 24, 453-470. [CrossRef]

93. Sharma, S.; Henriques, I. Stakeholder influences on sustainability practices in the Canadian forest products industry. Strateg. Manag. J. 2005, 26, 159-180. [CrossRef]

94. Jennings, P.D.; Zandbergen, P.A. Ecologically sustainable organizations: An institutional approach. Acad. Manag. Rev. 1995, 20, 1015-1052. [CrossRef]

95. Hoffman, A.J.; Ventresca, M.J. The institutional framing of policy debates: Economics versus the environment. Am. Behav. Sci. 1999, 42, 1368-1392. [CrossRef]

96. Prakash, A. A new-institutionalist perspective on ISO 14000 and Responsible Care. Bus. Strategy Environ. 1999, 8, 322-335. [CrossRef]

97. Bansal, P.; Clelland, I. Talking trash: Legitimacy, impression management, and unsystematic risk in the context of the natural environment. Acad. Manag. J. 2004, 47, 93-103.

98. Bansal, P. Evolving sustainably: A longitudinal study of corporate sustainable development. Strateg. Manag. J. 2005, 26, 197-218. [CrossRef]

99. Park, S.B. Multinationals and sustainable development: Does internationalization develop corporate sustainability of emerging market multinationals? Bus. Strategy Environ. 2018, 27, 1514-1524. [CrossRef]

100. Dyllick, T.; Hockerts, K. Beyond the business case for corporate sustainability. Bus. Strategy Environ. 2002, 11, 130-141. [CrossRef]

101. van Marrewijk, M. Concepts and definitions of CSR and corporate sustainability: Between agency and communion. J. Bus. Ethics 2003, 44, 95-105. [CrossRef]

102. Figge, F.; Hahn, T. Sustainable value added-measuring corporate contributions to sustainability beyond eco-efficiency. Ecol. Econ. 2004, 48, 173-187. [CrossRef]

103. Hahn, T.; Pinkse, J.; Preuss, L.; Figge, F. Tensions in corporate sustainability: Towards an integrative framework. J. Bus. Ethics 2015, 127, 297-316. [CrossRef]

104. Schaltegger, S.; Hansen, E.G.; Lüdeke-Freund, F. Business models for sustainability: Origins, present research, and future avenues. Organ. Environ. 2016, 29, 3-10. [CrossRef]

105. Stubbs, W.; Cocklin, C. Conceptualizing a "sustainability business model". Organ. Environ. 2008, 21, $103-127$. [CrossRef] 
106. Schaltegger, S.; Lüdeke-Freund, F.; Hansen, E.G. Business cases for sustainability: The role of business model innovation for corporate sustainability. Int. J. Innov. Sustain. Dev. 2012, 6, 95-119. [CrossRef]

107. Boons, F.; Lüdeke-Freund, F. Business models for sustainable innovation: State-of-the-art and steps towards a research agenda. J. Clean. Prod. 2013, 45, 9-19. [CrossRef]

108. Bocken, N.M.; Short, S.W.; Rana, P.; Evans, S. A literature and practice review to develop sustainable business model archetypes. J. Clean. Prod. 2014, 65, 42-56. [CrossRef]

109. Joyce, A.; Paquin, R.L. The triple layered business model canvas: A tool to design more sustainable business models. J. Clean. Prod. 2016, 135, 1474-1486. [CrossRef]

110. Amini, M.; Bienstock, C.C. Corporate sustainability: An integrative definition and framework to evaluate corporate practice and guide academic research. J. Clean. Prod. 2014, 76, 12-19. [CrossRef]

111. Held, M. Sustainable development from a temporal perspective. Time Soc. 2001, 10, 351-366. [CrossRef]

112. Gianni, M.; Gotzamani, K.; Tsiotras, G. Multiple perspectives on integrated management systems and corporate sustainability performance. J. Clean. Prod. 2017, 168, 1297-1311. [CrossRef]

113. Greening, D.W.; Gray, B. Testing a model of organizational response to social and political issues. Acad. Manag. J. 1994, 37, 467-498.

114. Oliver, C. Sustainable competitive advantage: Combining institutional and resource-based views. Strateg. Manag. J. 1997, 18, 697-713. [CrossRef]

115. Powell, W.W.; DiMaggio, P.J. The New Institutionalism in Organizational Analysis; University of Chicago Press: Chicago, IL, USA, 1991.

116. Scott, W.R. The adolescence of institutional theory. Adm. Sci. Q. 1987, 32, 493-511. [CrossRef]

117. Hörisch, J.; Freeman, R.E.; Schaltegger, S. Applying stakeholder theory in sustainability management: Links, similarities, dissimilarities, and a conceptual framework. Organ. Environ. 2014, 27, 328-346. [CrossRef]

118. Herremans, I.M.; Nazari, J.A.; Mahmoudian, F. Stakeholder relationships, engagement, and sustainability reporting. J. Bus. Ethics 2016, 138, 417-435. [CrossRef]

119. Dembek, K.; Singh, P.; Bhakoo, V. Literature review of shared value: A theoretical concept or a management buzzword? J. Bus. Ethics 2016, 137, 231-267. [CrossRef]

120. Horak, S.; Arya, B.; Ismail, K.M. Organizational Sustainability Determinants in Different Cultural Settings: A Conceptual Framework. Bus. Strategy Environ. 2018, 27, 528-546. [CrossRef]

121. Mitchell, R.K.; Agle, B.R.; Wood, D.J. Toward a theory of stakeholder identification and salience: Defining the principle of who and what really counts. Acad. Manag. Rev. 1997, 22, 853-886. [CrossRef]

122. Harrison, J.S.; Freeman, R.E. Stakeholders, social responsibility, and performance: Empirical evidence and theoretical perspectives. Acad. Manag. J. 1999, 42, 479-485.

123. Hart, S.L.; Sharma, S. Engaging fringe stakeholders for competitive imagination. Acad. Manag. Exec. 2004, 18, 7-18.

(C) 2020 by the authors. Licensee MDPI, Basel, Switzerland. This article is an open access article distributed under the terms and conditions of the Creative Commons Attribution (CC BY) license (http://creativecommons.org/licenses/by/4.0/). 